\title{
Juventudes, estetização da escola e artealização do cotidiano: olhar e imagens na pesquisa em educação
}

\author{
ARISTÓTELES BERINO
}

Resumo

O uso de imagens nas pesquisas em educação é cada vez mais frequente, constituindo um campo de debates e crescente produção acadêmica. $\mathrm{O}$ artigo dialoga com esse campo de investigações, apresentando uma discussão sobre juventudes e estetização da escola a partir de fotografias feitas pelo autor quando lecionava na rede pública municipal do Rio de Janeiro. O uso de imagens nas pesquisas propicia

Palavras-chave: Juventudes, imagens, estetização da escola uma via para análise das realizações estéticas juvenis nas escolas, fonte importante para concepção da educação popular hoje no Brasil. 


\title{
Youths, aesthetization of school and artealization of quotidian: look and images in research on Education
}

\author{
ARISTÓTELES BERINO
}

\begin{abstract}
The use of images in research on Education has been more frequent recently, creating a field of debates and an increasing academic production. The article deals with this field of investigation presenting a discussion about youths and aesthetization of school, developed by pictures taken by the author while he taught at municipal public schools in Rio de Janeiro. The use of images provides analysis of juvenile aesthetic accomplishments in schools, important source for conceiving popular education today in Brazil, and the perspective assumed by the author while writing the article.
\end{abstract}




\section{Juventudes, estetización de la escuela y artealización del cotidiano: mirada e imágenes en la investigación educativa}

\section{ARISTÓTELES BERINO}

\section{Resumen}

El uso de imágenes en investigaciones educativas es cada vez más frecuente, estableciendo un campo de debates y creciente producción académica. El artículo dialoga con ese campo de investigaciones, presentando una discusión sobre juventudes y estetización de la escuela a partir de fotografías tomadas por el autor cuando enseñaba en el sistema público del ayuntamiento de Rio de Janeiro. El uso de imágenes en las investigaciones

Palabras-clave: Juventudes, imágenes, estetización de la escuela proporciona un camino para el análisis de las realizaciones estéticas juveniles en las escuelas, fuente importante para la concepción de la actual educación popular en Brasil. 
Então deixaremos as imagens falarem por si só

Banda à Parte (1964), filme de Jean-Luc Godard

\section{Partilha}

"Minha imagem já saiu do Brasil [...], mas a minha pessoa nunca teve essa oportunidade de ir para o exterior".

Agosto de 2012. Baianinho está viajando para a Inglaterra, onde se apresentará, com outros dançarinos do "passinho", em um evento artístico dos Jogos Paralímpicos. Registro feito para o documentário A Batalha do Passinho - O Filme (2012), dirigido por Emílio Domingos.

Sugestiva para a nossa época essa concepção de uma existência dupla. Existe a "pessoa" e ainda a vida da sua "imagem". Não são duas entidades absolutamente separadas e autônomas, mas fazem parte, ao mesmo tempo, da mesma pessoa e de um indivíduo múltiplo, replicado. Contrariando a noção de unidade do sujeito, tese tão cara à modernidade, tal reprodução não é uma restrição, mas potência para uma vida expansiva e criativa. Sua "imagem" poderá ir à sua frente, conquistando espaços/territórios que "você" irá ocupar mais adiante, avançando sobre o tempo. Conquista que só é possível através dessa capacidade de viver o presente e experimentar imediatamente seus possíveis deslocamentos. Mas isso é realmente possível? Baianinho, na sua narrativa, refere-se aos vídeos que, postados no YouTube, permitem instantâneas e múltiplas visualizações das suas perfomances no passinho, que ultrapassam os limites estritamente físicos da sua presença no tempo e no espaço. Baianinho é real e virtual. E ele ainda suspeita da existência de uma vantagem da imagem sobre a realidade: "só internet, só internet, só internet, acho que isso não é nem um dançarino pessoal, é dançarino virtual”. 
Morador de uma das muitas chamadas "comunidades" da cidade do Rio de Janeiro, Baianinho descobriu que uma vida artista é modo de vida atraente para quem precisar "correr atrás" essa condição desfavorável para um contingente bastante significativo das populações das cidades, que não pode permanecer onde está sob o risco da invisibilidade social. Para os pobres, a "vida artista" é uma realização cotidiana de prazer/sucesso/mobilidade em cidades que promovem a exclusão social. É uma forma de vivacidade - uma viva negação das carências e faltas sempre endereçadas às suas existências. E é atraente também porque atrai para as suas vidas alguma estima por parte de outros segmentos da sociedade - grupos mais beneficiados, geralmente das classes médias, que também participam dos jogos de poder que sedimentam ou questionam os "lugares marcados" na vida da cidade. Dito de outro modo, manifestações culturais como o passinho participam das disputas por hegemonia na sociedade. Pulsão que estimula cultural e artisticamente as "periferias", hoje reconhecidamente mais dotadas de formas criativas que as áreas "centrais" das cidades. O reconhecimento adquirido pelo dançarino do funk é também um reconhecimento da existência e das demandas das classes populares.

Enquanto assisto Baianinho no DVD, sua imagem vai se espalhando diante dos meus olhos. Ele poderia ter sido meu aluno, penso. Em algum momento, foi aluno de uma escola pública ou, quem sabe, ainda estuda em uma delas. Ele é muito parecido com muitos alunos que conheci na rede pública municipal do Rio de Janeiro. Jovem, morador da periferia, praticando determinada linguagem, demonstrando sagacidade, entre algumas outras características, é, sem dúvida, um personagem que vi muitas outras vezes. Baianinho é uma personalidade, mas é também uma pessoa comum. Poderia ser outro. São muitos os indivíduos que poderiam estar ali, em destaque. Também por isso podem ser tão descartáveis quando enredam pelo mainstream. No entanto, não é aqui, no alto da cabeça do capitalismo artista, conceito utilizado por Gilles Lipovetsky e Jean Serroy (2015) para caracterizar o atual momento de estetização do mundo, que devemos nos fixar se desejamos dialogar, através das nossas pesquisas, com as "visualidades jovens" das classes populares. Existem outras "telas" para as suas projeções, superfícies mais mundanas, onde imprimem também suas existências, antes mesmo de publicarem suas imagens no YouTube.

Apesar da adversidade em que vivem, as juventudes das classes populares conquistam territórios que estão muito além 
dos avanços obtidos no mercado cultural - que também são importantes, mas não podem ser apropriadamente contabilizados sem a apreciação desses outros domínios. E o modo como realizam tais confrontos - produções comportamentais, comunicacionais e estéticas - marcadamente imagéticas, estão expandindo os nossos conhecimentos sobre as suas capacidades de expressão no mundo e de interpelar o poder. Sobretudo, porque são imagens-ações que "vivem" e se reproduzem na vida cotidiana. É no agenciamento ordinário da partilha do sensível (RANCIÈRE, 2005) que as juventudes das classes populares melhor lançam suas vidas, interferem no coletivo político da cidade e também virtualizam sua futuridade. Tendo em vista que a vida juvenil encontra nas escolas uma intensa cotidianidade e sucessivos desafios diante das normas, prescrições e contenções, é aí, entre salas de aulas, corredores, pátios e outros espaços, que tantas realizações cintilam, fraturando o que foi preparado para as suas presenças e as emergências ascendem às costas do instituído, propondo outras experiências e outros destinos - portanto, outros tantos saberes.

Olhando hoje para a escola, sobretudo, das chamadas grandes redes públicas (municipal e estadual), uma interferência juvenil em seus cotidianos chama atenção - embora, solicite um determinado olhar, ou seja, uma observação que permita ir além da vista embotada que nada enxerga senão desinteresse, apatia ou inadequação. Vou chamar essa interação - uma intromissão até - de estetização da escola. O que é? Uma artealização do seu cotidiano. A presença juvenil nessas escolas não tem nada de alienada, desatenta ou vulgar. Trata-se de uma presença produtiva, ainda que suas realizações nem sempre correspondam ao prescrito pelo estamento da educação. Meninos e garotas que ocupam tempo e espaço escolar com condutas, gestos e sinais que são, sobretudo, produções estéticas, realizações que conflitam com as pretensões de governo do lugar, caracteristicamente de forma artealizada: performances, poses, pichações, rabiscos, cores, vestimentas, enfim, uma constelação de imagens. Aqui também vivem duplamente - é o nome na chamada e suas projeções em todo o prédio escolar.

\section{Imagens}

Sua figura chama atenção para dois detalhes. Em cada um dos pulsos utiliza uma pulseira de borracha, uma branca e outra preta. Se estivesse usando apenas uma delas talvez esse detalhe não fosse percebido. Ao utilizar duas pulseiras, cada uma 


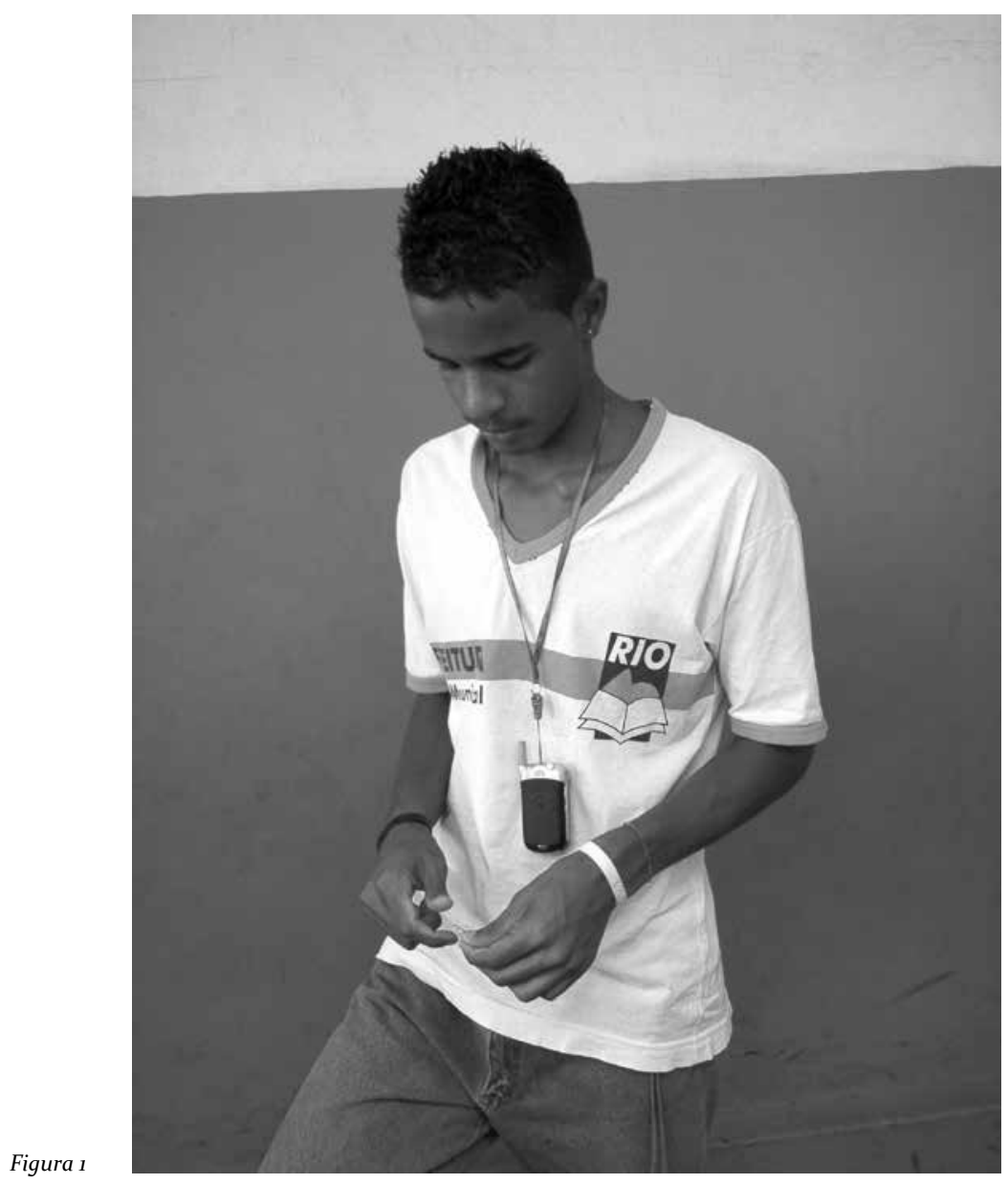

de uma cor, deixa claro uma dedicação com a sua imagem. Está na escola, mas não exatamente devotado à imagem de "aluno". Nem o uniforme escolar municipal promove a sua vida de estudante. Na cidade, serve para mostrar que está matriculado em uma "escola" e que, portanto, não é mais um jovem absolutamente desocupado, uma virtual ameaça para a sociedade. Efeito relativo porque estudar em uma escola municipal, entre os valores e as ideologias que expressam a vida na cidade do Rio de Janeiro, é uma má fortuna. Inclusive o detalhe laranja do uniforme muitas vezes foi associado ao uniforme dos garis da cidade. Infelicidade dos garis, que realizam um trabalho socialmente desvalorizado, mas também dos alunos das escolas públicas municipais, provocados a propósito de um futuro nada animador até pelas significações que carregam no 
uniforme. No entanto, em contraste com essas e outras adversidades, especialmente circunscritas às classes populares, há uma inegável delicadeza na sua representação como jovem. O uso simétrico das pulseiras (uma em cada pulso) e de cores que contrastam (o branco e o preto) realiza, ao mesmo tempo, um resultado atrativo, de equilíbrio, sugerindo um senso estético proporcional e harmônico.

No entanto, outro enfeite no seu corpo parece exagerado e exótico: quase na altura da barriga, um celular suspenso por um cordão preso ao pescoço. Entre os cuidados para promover a sua beleza, o celular ali parece uma excentricidade, uma exibição até de mau gosto. Ostentar determinados bens e objetos muitas vezes expressa não o poder econômico, mas uma satisfação limitada e constrangida pela pobreza. O celular é um desses objetos. Quando começou a se popularizar, ouvi inúmeras vezes: "a pessoa não tem dinheiro nem para comer, mas compra celular". A posse comum do celular produzia um ressentimento nas classes médias. Não era para todo mundo usar. Jovens das classes populares sabem disso. Cobiçam o celular e têm a exata noção da invasão que promovem sobre um consumo que deveria ficar restrito a uma aristocracia da cidade. A observação sobre a impropriedade da posse é acentuada por uma nota sobre o design envelhecido e o atraso da compra. "Coisa de pobre". Mas meu aluno está "ligado". Percorrendo tantas imagens, oferecidas por inúmeras mídias, sabe que a inclusão de objetos em espaços inusitados vai bem para uma figuração contemporânea. Isso é "arte". E a relevância atribuída ao celular não é a mesma que existe entre as classes mais abastadas. Como mídia para comunicação, parece reunir os mesmos usos, mas as apropriações abrem-se, de acordo com quem faz esses usos. As classes populares singularizam os objetos e podem tecer outras significações para eles.

No mesmo dia, depois de ter feito algumas fotos com os meus alunos, segui com as minhas aulas. Entre uma turma e outra, vivi um interessante episódio, motivo para outra pequena sequência de imagens. Ao entrar em uma sala, meus alunos me esperavam, depois de um tempo que estava vago para eles. Sem atividade escolar, resolveram ouvir música. Foi essa a cena que encontrei quando entrei na sala: um grupo de rapazes ouvindo funk. Eles não estavam sozinhos, ficaram me aguardando na companhia de um inspetor da escola - certamente enviado para não permitir nenhuma desordem enquanto permaneciam sem aula. Então, ao ver a minha presença, o inspetor andou na direção contrária para sair da sala. 


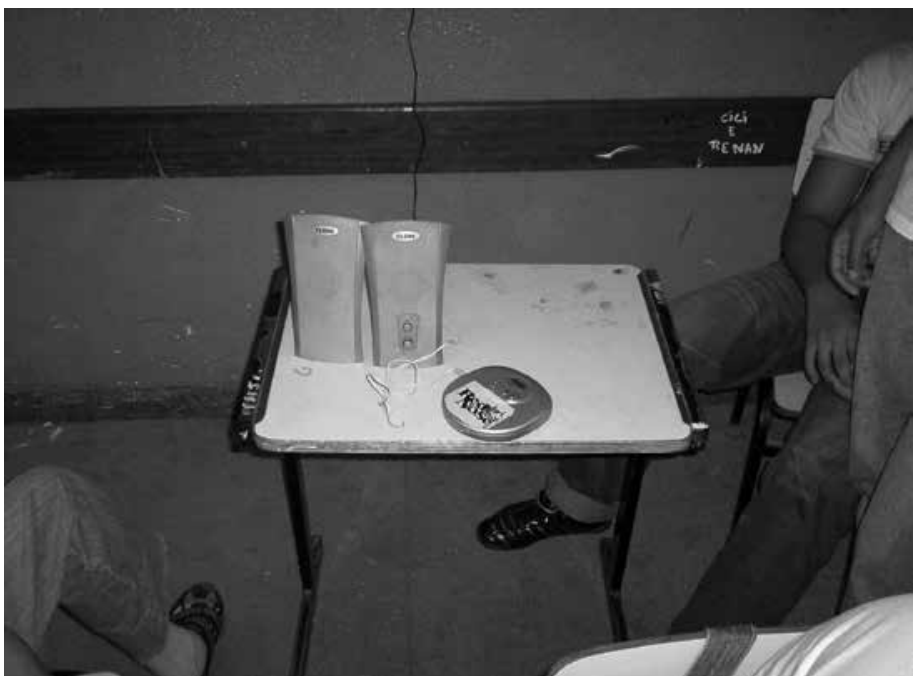

Ao passar por mim, disse: "Eles dizem que é cultura". Tive dificuldades para reagir ao comentário. Ele esperava a minha imediata reprovação a propósito do gosto musical dos meus alunos, além de condenar a própria audição na escola. Vi que iria decepcionar o inspetor; estava adorando encontrar meus alunos ouvindo funk. Principalmente, estava adorando pela forma como tudo estava acontecendo. Não podiam entrar na escola com dispositivo algum para ouvir música e lá estavam eles com um compacto discman e caixas acústicas portáteis.

Alguns anos antes, em outra escola, a diretora me pediu para não usar boné no lugar. Ela explicou: "não é permitido aos alunos, então, melhor o professor não usar também". Sim, sem problemas. Mas por que os alunos não podiam usar boné? O motivo de fundo é a necessidade dos corpos dóceis, agora conjugada com a recusa da cultura jovem das classes populares nas escolas. A cultura popular só é admitida de forma controlada, administrada pelo currículo e outras práticas de governo escolar. Pois bem, o fato é que essa administração é cada vez mais difícil - também por isso o recorrente discurso catastrófico sobre o "fim da escola". Tecnologias digitais e a miniaturização dos dispositivos são apropriadas pelos alunos para subversões no cotidiano escolar. Meus alunos me mostraram uma mochila e como era fácil transportar aqueles objetos para dentro da escola e até guardar rapidamente se necessário para burlar a vigilância. Realmente interessante esse uso dos aparelhos portáteis para ouvir suas músicas nas escolas. Esses objetos frequentemente estão associados à experiência 


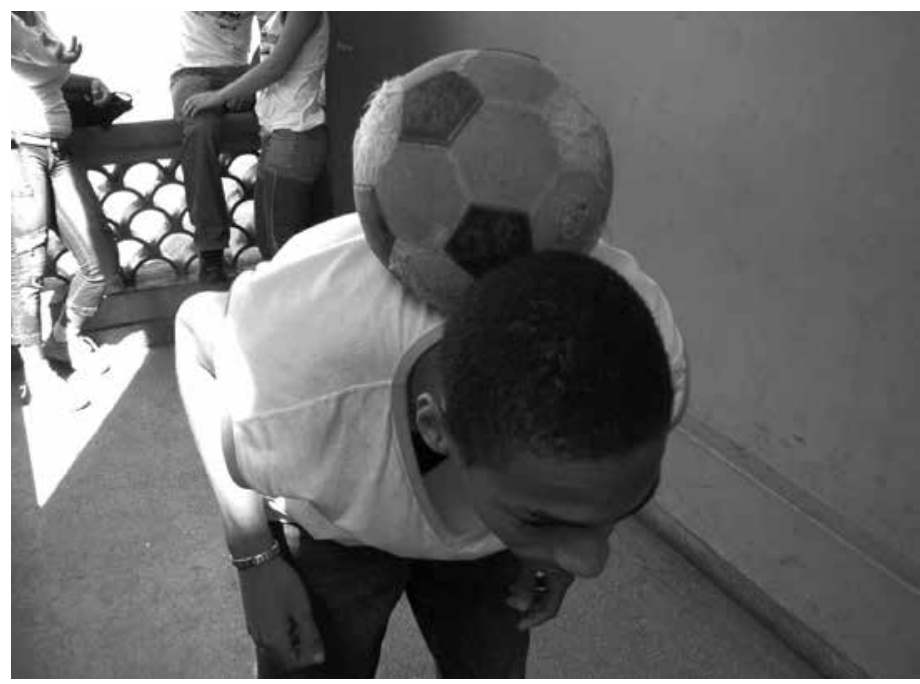

mais privatizada da vida. Como sucessor do walkman, o discman foi concebido para uma audição particular. No entanto, muitos jovens, em grupo, preferem o uso aberto e coletivo do aparelho. Naquele instante, o que mobiliza cada um é o efeito especial da música para a reunião do grupo. Nada demais, como se estivessem no bairro. No entanto, na escola o gesto desestabiliza sua suposta missão de promover uma vida urbana disciplinar e civilizada.

Retorno às imagens que fiz uma hora antes. Estamos no intervalo. Um dos alunos, que um pouco mais tarde estará no grupo que ouve funk na sala de aula, pega uma bola e faz alguns movimentos com ela. Como é o horário da recreação, é possível alguma distração com a bola sem ser lembrado de alguma proibição. Não é que a brincadeira passe despercebida e não provoque julgamentos. Recordo-me agora de outro episódio, dessa vez em outra escola, alguns anos antes. A diretora adjunta entra na sala e chama atenção dos alunos. Ela diz que eles correm muito durante o recreio e em consequência disso retornam suados e sujos à sala de aula. Havia na sua fala um tom muito duro de reprovação e até de repulsa. As produções corporais vitalizam, mas esse incitamento juvenil é um problema para as escolas. Há o temor que alguma nódoa espalhe suas impurezas pelas superfícies e pelos fundamentos da escola, manchando seu dever educacional. Assim, apesar do gesto banal do meu aluno com uma bola no horário do recreio, a insignificância do seu movimento estala os meus sentidos. A tentativa de alguma habilidade com a bola não é apenas uma demonstração 
física da sua juventude, mas um brilho passageiro entre as escassas oportunidades de triunfo que a escola proporciona. Ali ninguém ascende. A escola é incomunicável com esses jovens. Meninos e meninas precisam inventar quase sozinhos seus conhecimentos, desenvolvendo nos espaços mais restritos as capacidades mais radiantes. Então, na verdade, o que existe na imagem é uma raridade, um instante de beleza.

As três imagens que apresentei aqui são apenas algumas entre as muitas que fiz na escola. Três imagens sem nada de excepcional. Acredito que apenas a segunda imagem contém elementos que exibem um acontecimento mais exclusivo da vida nas escolas, dentro de uma sala de aula. As outras duas não contêm nenhum contexto particularmente destacável. Na verdade, são cenas de episódios comuns entre muitas escolas públicas. E é isso que gostaria de enfatizar. O que existe de especial nelas, é exatamente a aparente banalidade dos seus acontecimentos. No entanto, são imagens que nos permitem notar e problematizar a estetização das escolas, realizações juvenis que nas escolas tecem cenários artealizados que estão entre os mais vitais para a vida desses jovens no seu cotidiano - e, portanto, cujo reconhecimento pelas pesquisas e também pelas políticas públicas implicadas com a escolarização dos jovens das classes populares me parece necessário. A vida social sempre foi artística e nunca foi estranha à vida nas escolas a fruição estética como uma dimensão do seu cotidiano. Gostaria de lembrar, por exemplo, o filme, Zéro de Conduite (1933), de Jean Vigo, que realizado há mais de 80 anos, já interpelava a instituição escolar não apenas explorando a experiência da ética, mas também os seus sentidos estéticos. $\mathrm{O}$ inspetor $\mathrm{Hu}-$ guet, gracioso educador, a contrapelo da mortífera autoridade escolar, enleva o cotidiano escolar a práticas de fortalecimento dos jovens e aprazíveis práticas pedagógicas (BERINO, 2010). A questão, portanto, não é de novidade, mas de premência.

\section{Olhar}

Quando comecei a me interessar pelo uso de imagens nas pesquisas em educação, iniciei através da observação de diferentes espaços da escola. Percorria corredores, salas de aula ou áreas abertas. Tinha interesse também pelas paredes, em observar como eram utilizadas, preenchidas. Eu me detinha principalmente nos usos dos espaços, nos fluxos ou nas barreiras estabelecidas. Não se tratava de um registro etnográfico, mas um olhar educado pela experiência diária como 
professor. Depois de ter lecionado em aproximadamente seis escolas públicas, o que via não enxergava exatamente como um "pesquisador". Olhar e analisar, para mim, era uma prática de pertencimento. Reparava a preocupação sempre tensa da autoridade escolar com a movimentação dos alunos no interior da escola, inclusive o rigoroso controle do tempo de permanência no lugar, isto é, o horário admitido para a entrada e o obrigatório para a saída. Muitas vezes tinha a impressão que os alunos não eram motivo da existência da escola, mas presenças indesejáveis. Na impossibilidade de evitar abertamente esses jovens, a saída é redobrar a vigilância, reforçar o controle. Prédios são alterados - em relação à sua construção original - para máxima regulação de quem frequenta a escola. Grades eram acrescidas, por exemplo. O espaço é organizado também prevendo a inevitável movimentação dos alunos, com o estabelecimento de regras e de limitadas oportunidades de uso do estabelecimento. A biblioteca é um exemplo.

Não tenho ressentimentos da época, entre 1993 e 2006, em que lecionei nas escolas públicas. No entanto, são recordações ásperas e sem uma lembrança implicada com a emoção vivida naquele período. Impossível perscrutar esse passado com a ética devida aos alunos que conheci - a mesma população que hoje frequenta escola pública e na maioria das vezes é sumariamente avaliada e até condenada por seus gestos e comportamentos, sem que o público externo a essas escolas tenha razoável noção de como pode ser amarga a vida na maior parte dessas escolas ou, pelo menos, na maior parte do tempo em muitas delas. Agora em que imagens da vida cotidiana das escolas podem ser facilmente realizadas e disponibilizadas para tantas pessoas, que poderão compartilhar e emitir um sem fim de comentários sobre o que assistem, acredito que existe a necessidade de um diálogo das pesquisas com imagens em educação com esse público das redes sociais, debatendo o que estão vendo, levando em conta a complexidade midiática e cultural que cerca o que é "revelado", sem o simplismo das conclusões imediatas. Vídeos que mostram alunos em diversos episódios nas escolas rodam no YouTube, são vistos no Facebook e tornam-se "virais", muitas vezes exibindo situações que facilmente mobilizam nossa crítica, mas que enredam contextos que exigem análises mais compreensivas do que se passa, nem sempre colocadas à prova pela curiosidade - que na maioria das vezes não ultrapassa a compulsão pela apreciação superficial, acrescido pelo recorrente preconceito existente em relação às classes populares. 
Comecei a fotografar a partir do ano de 2004, na última escola municipal em que lecionei. O período do início desses registros coincide com a popularização das máquinas digitais. Sem formação em fotografia e sem utilizar qualquer equipamento profissional, minha prática como fotógrafo faz parte, portanto, da mesma cultura das imagens que desde as últimas duas décadas transformou todos em "fotógrafos". Inclusive, interesse que também atingiu as juventudes nas escolas, ainda muito mais aficionada e criativa no seu uso comum. Na verdade, usar imagens nas pesquisas em educação é um gesto que apenas acompanha (tenta acompanhar...) o que os jovens já fazem com elas. O interesse desses jovens pela imagem revelou-se tão agudo que logo mudei o meu objetivo com a fotografia. Como narrei antes, eu queria registrar diversos espaços da escola - silenciosamente, sem chamar atenção e sem fotografar ninguém. Contudo, se alguém me via com a máquina, meu aluno ou não, pedia para ser fotografado. Sempre achei curioso: até o meu último ano na escola nunca me pediram uma cópia da imagem feita, apenas pediam para que eu fizesse uma foto deles. Mesmo depois, quando iniciei outra série de imagens nos/dos/com os cotidianos, no CTUR - Colégio Técnico da UFRRJ, os alunos nunca me pediram para que fossem compartilhadas com eles. É como se essas imagens estivessem liberadas para viver seus destinos, até inconscientes para o modelo "original" que é cada pessoa.

Portanto, a consequência dessa intromissão juvenil nas minhas imagens foi uma inversão. Deixei de me interessar pelo poder, visto através de um olhar fotográfico, em troca de retratos da viva presença das juventudes nas escolas, também vistas através de imagens. Eu já não queria registrar a aparição difusa do poder em tantos espaços do cotidiano escolar. Passei a considerar essa possibilidade uma "homenagem" ao poder, uma rendição à autoridade escolar. As análises sobre a vida nas escolas pagam um tributo demasiado ao poder. Como marxista não deixo de reconhecer que estamos entre os maiores obsessivos pelo reconhecimento das suas práticas. Isso não cega? Então, provocado, abri meus olhos para os corpos que se ofereciam às realizações de imagens que, acredito, contrariam muitas das nossas visões a respeito do que se passa nas escolas, inclusive em relação ao governo do seu cotidiano e às hostilidades, contrariedades e resistências que produzem um denso cenário propício a outras proposições sobre a educação. Pessoas que sempre estiveram ali, exibindo-se até. Existem, no entanto, elementos políticos e culturais no nosso olhar, relacionados à nossa visão de mundo, aos nossos sa- 
beres e à nossa sensualidade. Relacionados, portanto, à nossa formação e disposição para se deformar, tecendo (ou não) continuamente novas compreensões sobre o mundo e suas transformações - caminhando com o mundo, evitando convicções tão definitivas e fundamentalismos do olhar.

Nas escolas, a relação quase diária com tantos jovens provocava meu interesse por referenciais teóricos que pudessem também colaborar, favorecendo um olhar mais sensível e abrangente sobre acontecimentos, fantasias ou frustrações que, de algum modo, todos os seus "residentes" ali partilham. Diante das propriedades e futuridades da nossa época, a sociologia das emergências, de Boaventura Sousa Santos (2007), a vida comunitária em Michel Maffesoli (2010) e as horizontalidades em Milton Santos (2001), estão entre as férteis conversas com a teoria social, pertinentes à minha consideração pela vida nas escolas. Em relação às discussões diretamente associadas ao campo educacional, a pedagogia do oprimido de Paulo Freire (2005), o currículo território em disputa de Miguel Arroyo (2011) e as pesquisas nos/dos/ com os cotidiano de Nilda Alves (2001) e também Inês Barbosa de Oliveira (2012) e Aldo Victorio Filho (2002) são relevantes referências para o meu pensamento. Frente aos desafios para a escola no século XXI, principalmente para aquelas concebidas para a frequência das classes populares, há um cansaço provocado pelas narrativas e práticas hegemônicas da modernidade, inclusive nas pesquisas. São projetos esgotados que hoje levam apenas ao reconhecimento da falência da escola ou do esgotamento das forças que poderiam recuperá-la. Todos parecem procurar "onde está Wally" e não encontram. Necessário olhar/pesquisar de outro modo, como muitos já estão fazendo.

A escola precisa ser vista, antes de tudo, credibilizando seus personagens no lugar de esperar por outros. Mais do que qualquer balanço que nos apresente os números da escola, com a fatura que nunca foi paga, melhor olhar para o presente, mirar para o que está sendo tecido por tantos jovens à espera de contatos. São jovens que se mostram para muitos diálogos. Suas imagens são comunicativas. Eles querem conversas. A estetização das suas presenças nas escolas não deve ser recepcionada apenas com elogios à "diversidade cultural", aparentemente educada e elegante, essa colonial tolerância, forma de recolonização das suas vidas, enquadrando-as, quando possível, na concepção escolar de cidade única e pacificada (BERINO, 2006). A melhor recepção é aquela marcada pelo encontro aberto ao conhecimento mútuo e os caminhos para isso inventados em cada lugar, implicados com as demandas, os anseios e as melhores 
perspectivas para as classes populares. A artealização do cotidiano escolar é tão sedutora que tantos pesquisadores poderiam receber como um convite ao trabalho e diálogo com essas imagens. Constituem, com efeito, outra via para conhecermos mais esses jovens. São imagens que não existem como meras representações das pessoas que são, mas constituem formas vivas, expansões da existência que nas escolas pedem outros modos de olhar e de viver no lugar.

\section{Referências}

ALVES, N. Imagens das escolas. In: ALVES, Nilda; SGARBI, Paulo (Org.). Espaços e imagens na escola. Rio de Janeiro: DP\&A, 2001. p. 7-17.

ARROYO, M. Currículo, território em disputa. Petrópolis: Vozes, 2011.

BERINO, A. A economia política da diferença. São Paulo: Cortez, 2010.

. Zero em Comportamento: o inspetor huguet - cinema e a virtualização dos currículos praticados. In: LOBO, Roberta (Org.). Crítica da imagem: reflexões sobre a contemporaneidade. Rio de Janeiro: EPSJV, 2010. p. 273-283.

FREIRE, P. Pedagogia do oprimido. 44. ed. São Paulo, Paz e Terra, 2005.

LIPOVETSKY, G.; SERROY, J. A estetização do mundo: viver na era do capitalismo artista. São Paulo: Companhia das Letras, 2015.

MAFFESOLI, M. Saturação. São Paulo: Iluminuras/Itaú Cultural, 2010.

OLIVEIRA, I. B. de. O currículo como criação cotidiana. Petrópolis: DP/Rio de Janeiro: FAPERJ, 2012.

RANCIÈRE, J. A partilha do sensível: estética e política. São Paulo: Editora 34/EXO Experimental org., 2005

SANTOS, B. de S. Renovar a teoria crítica e reinventar a emancipação social. São Paulo: Boitempo, 2007.

VICTORIO FILHO, Aldo. A formação continua no cotidiano. In: VICTORIO FILHO, Aldo; CASTELLANO, Solange (Org.). Cultura e conhecimento de professores. Rio de Janeiro: DP\&A, 2002. p. 61-76.

Recebido em: 02/08/15

Aceito em: 02/09/16 


\section{ARISTÓTELES BERINO \\ aristotelesberino@yahoo.com.br \\ Doutor em Educação (2004) pela Universidade Federal Fluminense (UFF). Atualmente é professor associado I da Universidade Federal Rural do Rio de Janeiro (UFRRJ) no Departamento de Educação e Sociedade do Instituto Multidisciplinar (Campus Nova Iguaçu) e no Programa de Pós-Graduação em Educação, Contextos Contemporâneos e Demandas Populares (PPGEduc-UFRRJ). Publicou, entre outros trab- alhos, o livro A economia política da diferença (2007). Líder do GRPESQ Estudos Culturais em Educação e Arte.}

